\title{
A lump on the nose
}

\author{
Misha Verkerk, ${ }^{1}$ Jason Powell, ${ }^{2}$ Janet Wilson ${ }^{2}$
}

\begin{abstract}
${ }^{1}$ UCL Ear Institute, London, UK
${ }^{2}$ Department of

Otolaryngology, Freeman

Hospital, Newcastle-upon-Tyne, UK
\end{abstract}

\section{Correspondence to}

Misha Verkerk,

misha.verkerk.09@ucl.ac.uk

Accepted 26 October 2015

\section{CrossMark}

To cite: Verkerk $\mathrm{M}$, Powell J, Wilson J. BMJ Case Rep Published online: [please include Day Month Year] doi:10.1136/bcr-2015211806

\section{DESCRIPTION}

A young woman presented with prominence of the dorsum of her nose since childhood. She had become increasingly self-conscious of her appearance but was otherwise fit and well. She denied symptoms of nasal obstruction, epistaxis or discharge but described an intermittent ache related to the lump. There was no history of seizures, meningitis or cerebral abscess. Examination revealed a firm midline dorsal hump (figures 1 and 2). The rest of the examination was normal.

Nasal surgery was delayed into adulthood as not to impede nasal development. At the age of 19 years she underwent open septorhinoplasty for correction of what was thought to be a congenital osseocartilagenous deformity. A skin-coloured, fibrous mass of adipose tissue, skeletal muscle and nerve fibres was resected. This was histologically confirmed to be a subcutaneous hamartoma.

Hamartomas are benign tumours that represent the anomalous development of multiple tissue types native to the organ in which they are found. ${ }^{1}$ Most hamartomas are solitary, however multiple hamartomas may suggest tuberous sclerosis (associated with epilepsy), Cowden syndrome (macrocephaly, intestinal polyps, cutaneous hamartomas and increased cancer risk) or Proteus syndrome (overgrowth of skin, bones and other tissues). ${ }^{2}$

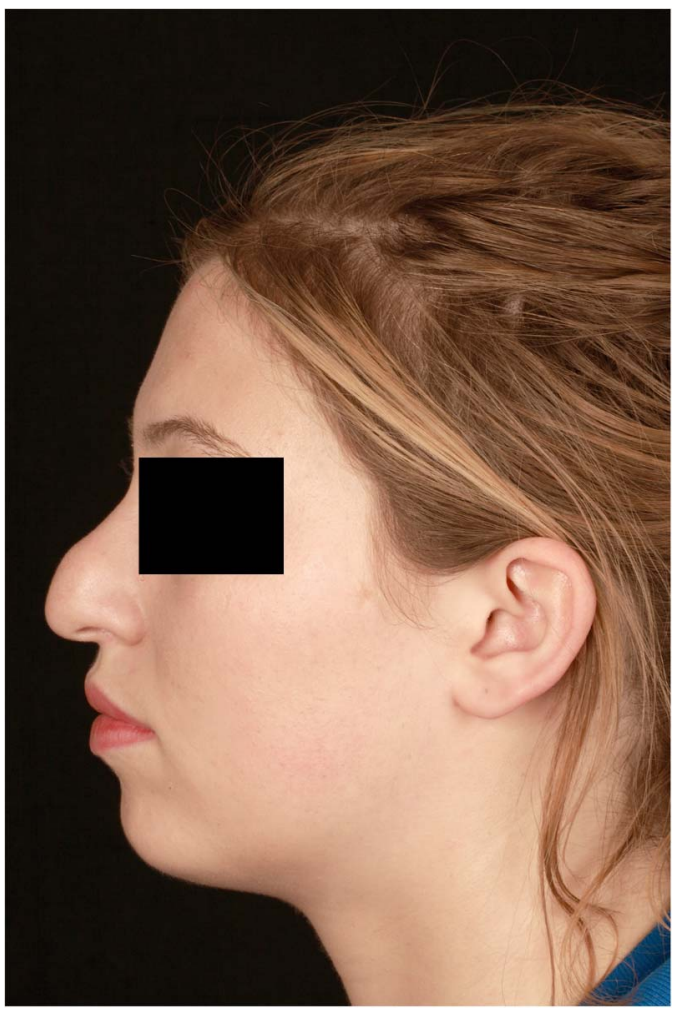

Figure 1 Preoperative clinical photography demonstrates prominent nasal dorsum.

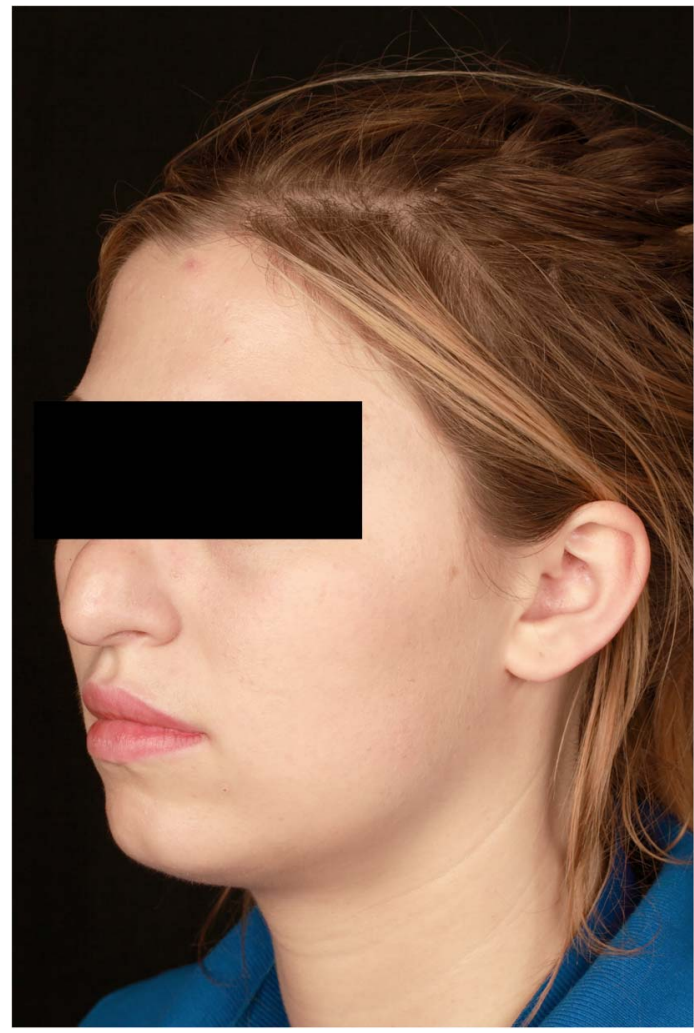

Figure 2 Anterolateral view.

Systematic review of the literature found this to be the first documented case of an external nasal dorsum hamartoma. Nasal dorsum abnormalities are typically bony variations of normal nasal anatomy. The differential diagnosis for congenital midline nasal masses also includes dermoid cysts, gliomas and encephalocoeles, which carry a risk of meningitis and cerebral abscess if they are found to contain intracranial connections. ${ }^{3}$

\section{Learning points}

- The differential diagnosis for congenital abnormalities of the nasal dorsum include bony variations in normal anatomy as well as dermoid cysts, gliomas, encephalocoeles and, rarely, hamartomas.

- Hamartomas are benign tumours and are usually sporadic.

- Multiple hamartomas can be associated with heritable syndromes.
Acknowledgements Dr Philip Sloan, for processing the pathological specimen and reaching the histological diagnosis. 
Contributors MV wrote and revised the manuscript and gained patient consent. JP wrote and revised the manuscript. JW identified the patient, managed the case, and revised the draft manuscript.

Competing interests None declared.

Patient consent Obtained.

Provenance and peer review Not commissioned; externally peer reviewed.

\section{REFERENCES}

1 Poomeechaiwong S, Golitz LE. Hamartomas. Adv Dermatol 1990;5:257-87.

2 Fistarol SK, Anliker MD, Itin PH. Cowden disease or multiple hamartoma syndrome-cutaneous clue to internal malignancy. Eur J Dermatol 2002;12: $411-21$.

3 Paller AS, Pensler JM, Tomita T. Nasal midline masses in infants and children. Dermoids, encephaloceles, and gliomas. Arch Dermatol 1991;127:362-6.

Copyright 2015 BMJ Publishing Group. All rights reserved. For permission to reuse any of this content visit http://group.bmj.com/group/rights-licensing/permissions.

BMJ Case Report Fellows may re-use this article for personal use and teaching without any further permission.

Become a Fellow of BMJ Case Reports today and you can:

- Submit as many cases as you like

- Enjoy fast sympathetic peer review and rapid publication of accepted articles

- Access all the published articles

- Re-use any of the published material for personal use and teaching without further permission

For information on Institutional Fellowships contact consortiasales@bmjgroup.com

Visit casereports.bmj.com for more articles like this and to become a Fellow 